\title{
STRUCTURE AND BIOMASS ANALYSIS OF URBAN VEGETATION IN SQUARES OF SANTA CECÍLIA DISTRICT, SÃO PAULO, SP
}

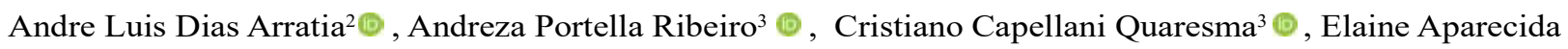
Rodrigues $^{4}\left({ }^{\circ}\right.$, Edgar Fernando de Lucca ${ }^{\odot}$, , Plínio Barbosa de Camargo ${ }^{5}$, Ana Paula Branco do Nascimento $^{6}$ and Maurício Lamano Ferreira $^{7^{*}}$

\footnotetext{
${ }^{1}$ Received on 11.04.2019 accepted for publication on 08.04.2020.

${ }^{2}$ Prefeitura Municipal de São Paulo, São Paulo, SP-Brasil. E-mail: <arratia.aa@gmail.com>.

${ }^{3}$ Universidade Nove de Julho, Programa de Pós-Graduação em Cidades Inteligentes e Sustentáveis, São Paulo, SP-Brasil. E-mail: $<$ aportellar@gmail.com> and <quaresmacc@uni9.pro.br>.

${ }^{4}$ Instituto Florestal do Estado de São Paulo, São Paulo, SP-Brasil. E-mail: <elainearodrigues@gmail.com> and <efluca@gmail.com>.

${ }^{5}$ Universidade de São Paulo, Centro de Energia Nuclear na Agricultura, Piracicaba, SP-Brasil. E-mail: < pcamargo@cena.usp.br>.

${ }^{6}$ Universidade Federal de São Carlos, Departamento de Genética, Piracicaba, SP- Brasil. E-mail: <apbnasci@alumni.usp.br>.

${ }^{7}$ Centro Universitário Adventista de São Paulo, São Paulo, SP-Brasil . E-mail: <mauecologia@yahoo.com.br>.

*Corresponding author.
}

\begin{abstract}
Urban trees play an important role in urban planning and are directly linked to urban spaces that promote ecosystem services such as biodiversity conservation and carbon stock. A useful methodology to quantify the above-ground (ABG) biomass, and consequently, the carbon stocks, in this green infrastructure is the allometric models made for tropical areas. This work aimed to evaluate the carbon stock in public squares within the central region of São Paulo city, thus contributing to the comprehension of São Paulo's green infrastructure. To test the models, tree density and ABG biomass of approximately 7 ha of urban green areas in the center of São Paulo city were evaluated. The activities involved measuring the diameter at breast height $(\mathrm{DBH})$ of the trees and the total height of all individuals with a DBH greater than $5 \mathrm{~cm}$. The results showed that the public squares varied in size and number of trees. The average height of trees also varied along the squares, probably influencing the ABG biomass allocation. Also, the results showed that there was a considerable variation between the ABG biomass estimated along the models. Some squares stood out in absolute terms of $\mathrm{ABG}$ biomass accumulation. The size of the green area correlated only with the total number of individuals found $\left(\mathrm{R}^{2}=0.44\right)$. The total $\mathrm{ABG}$ biomass, tree density, and $\mathrm{ABG}$ biomass density did not present a significant relationship with the size of the squares. This work demonstrates, for the first time, the attributes of tree communities in public squares of- São Paulo city and provides technical information for the management of public policies related to the protection and maintenance of urban green areas.
\end{abstract}

Keywords: Carbon Cycling; Allometry; Green Infrastructure.

\section{ANALLISE DA ESTRUTURA E BIOMASSA DA VEGETAÇÃO URBANA EM PRAÇAS DO DISTRITO SANTA CECÍLIA, SÃO PAULO, SP}

\begin{abstract}
RESUMO - As árvores urbanas desempenham um papel importante no planejamento urbano e estão diretamente ligadas aos espaços urbanos que promovem serviços ecossistêmicos, como por exemplo, conservação da biodiversidade e estoque de carbono. Uma metodologia útil para quantificar a biomassa acima do solo $(A B G)$ e, consequentemente, os estoques de carbono nessa infraestrutura verde, é feita através de modelos alométricos especificos para áreas tropicais. Este trabalho tem como objetivo avaliar o estoque de carbono em praças públicas da região central da cidade de São Paulo, contribuindo assim para a compreensão da infraestrutura verde da cidade. Para testar os modelos foram avaliadas a densidade das árvores e a biomassa de aproximadamente 7 ha de áreas verdes urbanas no centro da cidade de São Paulo. As atividades envolveram a medição do diâmetro na altura do peito (DAP) das árvores e a altura total de todos os indivíduos com DAP maior que $5 \mathrm{~cm}$. Os resultados mostraram que as praças públicas variavam em tamanho e número de árvores. A altura média das árvores também variou ao longo das praças, provavelmente influenciando a alocação da
\end{abstract}

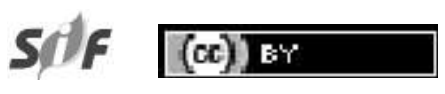

Revista Árvore 2020;44:e4417 http://dx.doi.org/10.1590/1806-908820200000017 


\begin{abstract}
biomassa acima do solo. Além disso, os resultados mostraram que houve variação considerável entre a biomassa estimada ao longo dos modelos. Algumas praças se destacaram em termos absolutos de acúmulo de biomassa $A B G$. O tamanho da área verde correlacionou-se apenas ao número total de indivíduos encontrados $\left(R^{2}=0,44\right)$. A biomassa total, densidade de árvores e densidade de biomassa ABG não apresentaram relação significativa com o tamanho das praças. Este trabalho demonstra, pela primeira vez, os atributos de comunidades arbóreas em praças públicas da cidade de São Paulo e fornece informações técnicas para o gerenciamento de políticas públicas relacionadas à proteção e manutenção de áreas verdes urbanas.
\end{abstract}

Palavras-Chave: Ciclo do Carbono; Alometria; Infraestrutura verde.

\section{INTRODUCTION}

The uncontrolled growth of urban centers, together with intense deforestation, has altered the landscape with serious ecological consequences. The Atlantic Forest encompasses most of the large cities in Brazil and features different forest formations with great species richness and floristic diversity, overcoming in some areas the tree diversity of the Amazon Forest (Tabarelli and Mantovani, 1990; Tanus et al., 2012; Eisenlohr et al., 2013). However, the biome underwent intense deforestation, as a result of the changes in land use and the expansion of the cities (Lapola et al., 2014). Thus, the urbanization process has brought serious consequences to the ecosystems, generating losses of biodiversity, biological homogenization and damages to ecosystem services in urban areas (McDonald et al., 2013; Ferreira et al., 2017a).

A very promising proposal that has been currently discussed to solve urban infrastructure problems involves the use of Nature-based solutions (Kabisch et al., 2017; Keesstra et al., 2018). Among several existing methodologies, the use of green infrastructure has been highlighted in scientific journals (Lafortezza et al., 2013; Sanesi et al., 2017) and in european government reports (EEA, 2011; EC, 2012).

Both biosphere and atmosphere are major carbon sinks (Zhang et al., 2015), and the sequestration or emission of $\mathrm{CO}_{2}$ plays an important role in the ecosystem dynamics (Saleska et al., 2003). Thus, the reduction of atmospheric carbon promoted by photosynthesis can imply climatic effects at local and regional scales (Malhi and Grace, 2000). The overall levels of carbon stored in trees differ among species, biome, geographical location and phytosociology (Scolforo et al., 2015). It is possible to measure carbon contents in vegetation by direct (destructive) methods or by allometric (nondestructive) modeling, which is a method widely used to assess above-ground biomass in tropical forests (Vieira et al., 2004; Higuchi et al., 2008; Vieira et al., 2008; Alves et al., 2010). These models are usually specific to communities of a particular region or to a special state of forest regeneration, e.g., primary or secondary forests (Burger and Delitti, 2008).

A problem intrinsic to above-ground biomass studies in urban green areas is the choice of a model that best represents or estimates the biomass value contained in the tree community in question. Since no specific allometric model is available for the vegetation of the São Paulo City, it is necessary to analyze the variability among the estimates provided by different existing equations, before proposing a method to evaluate the green areas of the city in the context of its green infrastructure.

In addition, Brazilian urban green areas have not received much attention when it comes to studies involving the quantification of biomass (Ferreira and Uchiyama, 2015; Ferreira et al., 2017b). As well as large expanses of native forest, urban green areas also provide significant environmental services to cities, which is a key tool to creating sustainable and healthy places.

An important environmental service provided by public green areas in urban centers is their capacity to store carbon (Díaz-Porras et al., 2014). As a consequence, $\mathrm{CO}_{2}$ emissions from automobile exhaust and industrial processes are compensated (Weissert et al., 2014). In turn, the urban flora, due to the interference of anthropic activities, has become as vulnerable as the natural forests. It so happens because these areas are modified by local regulars, which might influence the composition and the floristic structure by the direct planting of exotic species (Moro et al., 2014).

Therefore, taking into account the importance and functions of urban green areas, it is necessary to

Revista Árvore 2020;44:e4417 
understand the ecological characteristics inherent to them. An open question is whether tree density and biomass vary according to the size of the green area. Contrastingly to natural forests, such relationships are still unknown when it comes to urban green areas (Oertli et al., 2002; Villard and Metzger, 2014). Finally, as studies involving the capacity of urban green areas to stock carbon lack in Brazil, , this work also assesses the carbon stockage in public squares of the central region of São Paulo city, thus contributing to the comprehension of São Paulo's green infrastructure. It is important to highlight that the collection of these data may become the basis for the development of public policies aimed at the maintenance and expansion of such urban green areas.

\section{MATERIAL AND METHODS}

\subsection{Study area}

The study was conducted in ten public squares in the Santa Cecília District (Figure I), central region of São Paulo City, including the districts of Santa Cecília, Campos Elísios, Vila Buarque, Várzea da Barra Funda and Bom Retiro. According to the prefecture of São Paulo (Sao Paulo, 2020), the central region of the city totalizes $26,20 \mathrm{~km}^{2}$, and the district of Santa Cecilia occupies approximately $14 \%$ of this area $\left(3,9 \mathrm{~km}^{2}\right)$. The human population is estimated at about 86,132 inhabitants, with a population density of $22,726 \mathrm{Inh} / \mathrm{km}^{2}$ (SEAD, 2014).

São Paulo City is located 780 meters above sea level on the State of São Paulo plateau and presents a historical annual average rainfall of 1,500 $\mathrm{mm}$ and amean temperature of $25^{\circ} \mathrm{C}$ (IAG/USP, 2014).

The study area encompasses 7.1 hectares of urban green areas distributed in ten public squares. The squares of Santa Cecilia district were randomly selected according to the total area, including both green and paved areas.

Each square presents its own characteristics with respect to physical and structural attributes. The Santa Cecilia Square (LSC) includes a Catholic church that occupies most of the square area and a cemented courtyard sporadically used for festivals and other cultural and social activities. Its vegetation is limited to trees surrounding the church and a few gardens. The Princesa Isabel Square (PI) is densely vegetated with old trees. It is connected to an urban bus terminal with the same name. Large and medium trees are dispersed around the Marechal Deodoro Square (MD), where nearby hospitals and health units are reference points. PI and MD both include playgrounds and historical monuments. The Julio Prestes Square (JP) is located within a train station (São Paulo Metropolitan Trains Company). The State Symphony Orchestra House occupies part of this area, and the population is transient. Chão de Giz (SD), as described in this study, has been recently acknowledged by the São Paulo City Hall (PMSP) as a green area. It includes a few medium-sized trees and is located between two large avenues with heavy traffic. Antonio Cândido de Camargo (ACC), Olavo Bilac (OB), Padre Luis Alves de Siqueira Castro (PLASC), and Vicente Celestino (VC) squares include vegetation, cement benches and bus stops, and are typically frequented by local residents and merchants. The Torquato Tasso Neto Square (TTN) is not paved. Taxi drivers help maintain the square by planting fruit trees, thus contributing to the preservation and diversity of the site (Figure I).

\subsection{Structure and carbon stock in urban green areas}

One of the parameters obtained in the field for the quantification of the above-ground (ABG) biomass of each square of the study area was the Diameter at Breast Height (DBH). The Perimeters at Breast Height (PBH) of all trees greater than $14.8 \mathrm{~cm}$ were measured using a flexible tape graduated in millimeters. Trees along sidewalks surrounding the squares were also considered. Should aerial roots, calluses or obstruction appear at 1.30 meters above the ground, $\mathrm{PBH}$ measurements were taken $50 \mathrm{~cm}$ above these obstacles (Clark et al., 2001).

PBH data were then converted to DBH by dividing the measured perimeter by pi $(\pi)$. In case of branched trees, the PBH of each branch was measured.

To analyze the community structure, trees were separated into different DBH classes (up to $5 \mathrm{~cm}, 5-10$ $\mathrm{cm}, 10-15 \mathrm{~cm}, 15-20 \mathrm{~cm}, 20-25 \mathrm{~cm}, 25-30 \mathrm{~cm},>30 \mathrm{~cm}$ ). For the measurement of the height of each tree, a hand clinometer was used.

Because there is no specific model for urban green areas for São Paulo City, different equations were applied to estimate a probable $\mathrm{ABG}$ biomass range, considering also those that led to overestimated values of biomass (McHale et al., 2009).

Therefore, five different allometric models applied to tropical forest trees from the Atlantic Forest biome, in which the São Paulo City is located, were used to

Revista Árvore 2020;44:e4417 


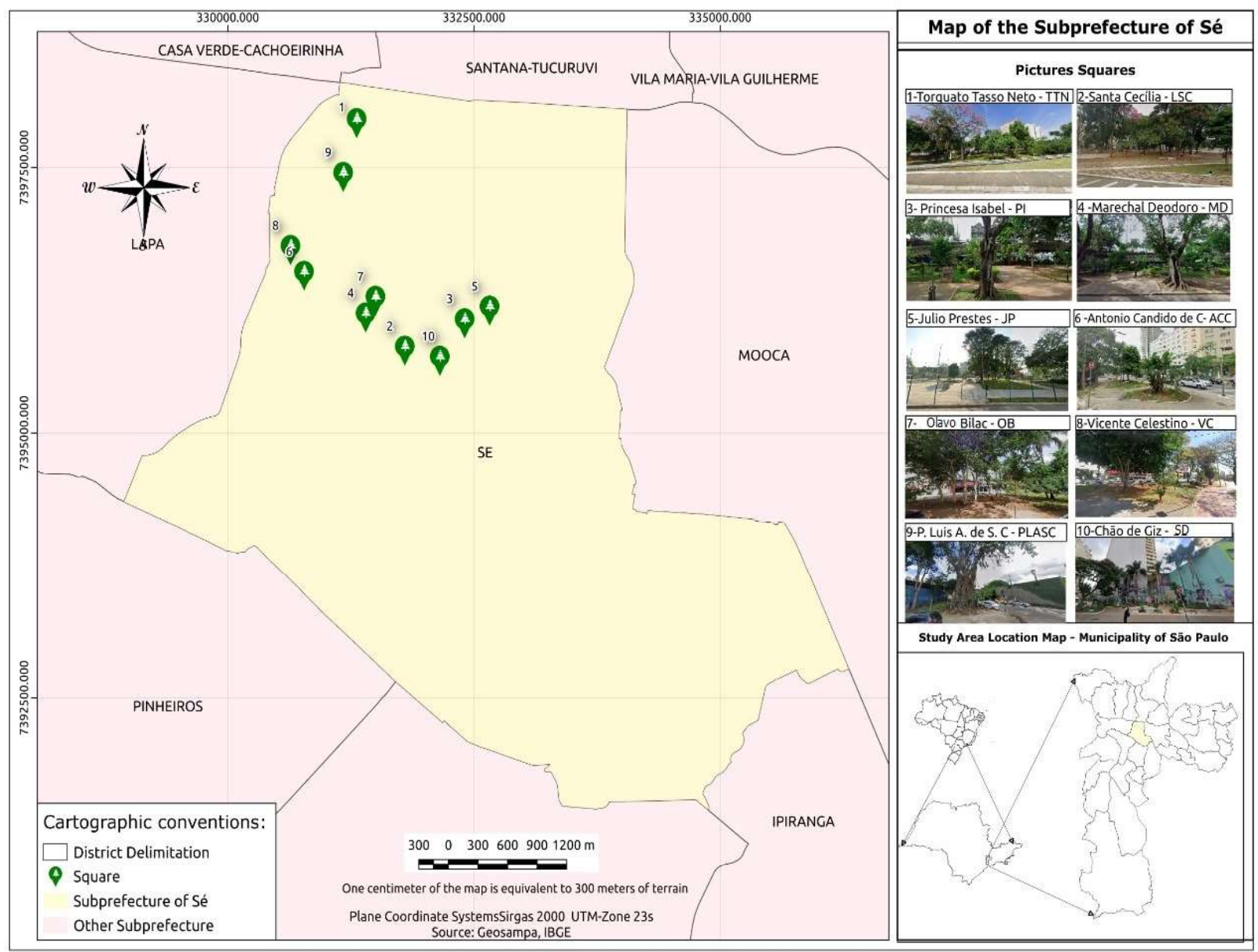

Figure 1 - Geographic location of the squares in the subprefectures of São Paulo City.

Figura 1 - Localização geográfica das praças nas subprefeituras dos bairros da cidade de São Paulo.

quantify biomass, namely: Arevalo et al. (2002) [1] and Tiepollo et al. (2002) [2], based only on DBH as the independent variable; the allometric model adopted by Scatena et al. (1993) [3], which used DBH and height as independent variables; the allometric model proposed by Chave et al. (2005) [4], which used tree wood density and DBH as independent variables, and Chave et al. (2014) [5], which adopted DBH, height and tree wood density as independent variables. It is important to highlight that Chave's model was recently elaborated with data from different pan-tropical forests (Chave et al., 2014). The equations of the used models are presented below (equations 1, 2, 3, 4 and 5):

$$
<A G B\rangle_{\text {est }}=\left(0.1184^{*} D^{2.53}\right)
$$

$$
\begin{aligned}
& \left.<A G B\rangle_{\text {est }}=21.297+(-6.953)(D)+0.740(D)^{2}\right) \mathrm{Eq} 2 \\
& <A G B>_{\text {est }}=\exp \left(-3.282+0.95\left(\ln (D)^{2} * \mathrm{H}\right)\right) \mathrm{Eq} 3 \\
& \left.<A G B\rangle_{\text {est }}=\rho \times \exp (-1.499+2.148 \ln (D))+0.207(\ln (D))^{2}-0.0281(\ln (D))^{3}\right) \mathrm{Eq} 4 \\
& <A G B\rangle_{\text {est }}=0.673 *\left(\rho D^{2} H\right)^{0.976}
\end{aligned}
$$

It is also important to stress that we used an estimated average value of wood density $\left(0.603 \mathrm{~g} / \mathrm{cm}^{3}\right)$ for the Atlantic Forest trees in the allometric equations of Chave et al. (2005) and Chave et al. (2014), as proposed by Vieira et al. (2008).

Carbon stock was considered as $50 \%$ of the biomass, since this procedure has been widely used

\section{Revista Árvore 2020;44:e4417}


Table 1 - Tree community structures in ten squares of the Santa Cecilia District, São Paulo, SP. The full square names are as follows: ACCAntonio Cândido de Camargo, VC-Vicente Celestino, LSC-Largo Santa Cecilia, SD-Chão de Giz, OB-Olavo Bilac, JP-Julio Prestes, MD-Marechal Deodoro, PLASC-Padre Luis Alves de Siqueira Castro, TTN-Torquato Tasso Neto, PI-Princesa Isabel. ANI- absolute number of individuals, SA- square area in $\mathrm{m}^{2}$, D-density (Individuals ha ${ }^{-1}$ ), NTT- number of branched trees, TNTtotal number of branches, AH- average height of trees.

Tabela 1 - Estrutura da comunidade arbórea de dez praças estudadas no distrito de Santa Cecilia, São Paulo, SP. As praças são indicadas da seguinte forma: ACC-Antonio Cândido de Camargo, VC-Vicente Celestino, LSC-Largo Santa Cecilia, SD-Chão de Giz, OBOlavo Bilac, JP-Julio Prestes, MD-Marechal Deodoro, PLASC-Padre Luis Alves de Siqueira Castro, TTN-Torquato Tasso Neto, PI-Princesa Isabel. ANI-número absoluto de indivíduos, SA-área da praça em $\mathrm{m}^{2}$, D-densidade (individuos ha-1), NTT-número de árvores com bifuracações, TNT-número total de bifurcações, AH-altura média das árvores.

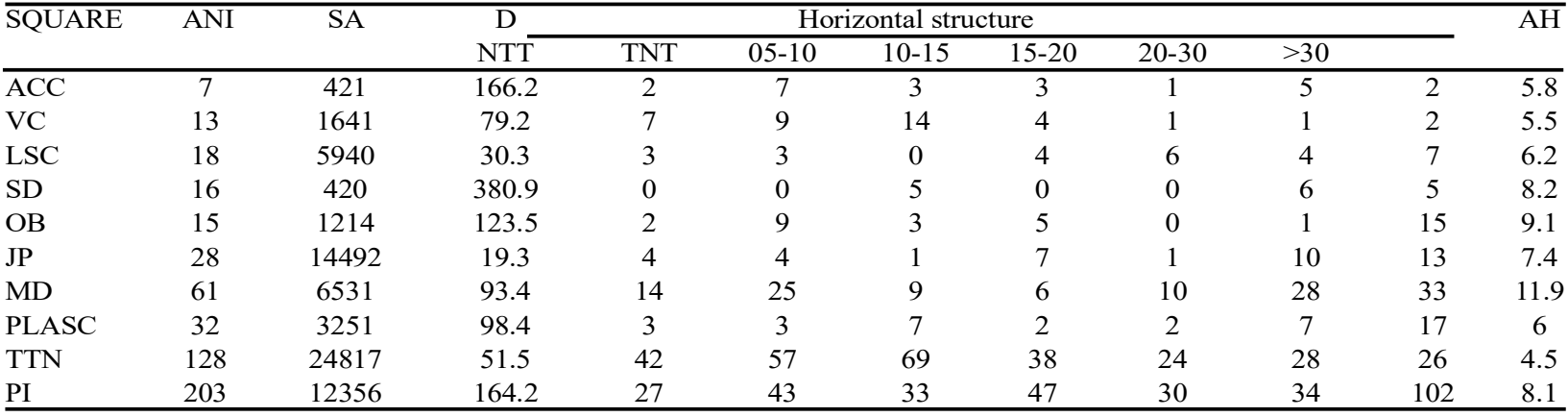

and reported in the scientific literature (Lewis et al., 2009; Saatchi et al., 2011). It should be noted that some authors have shown a possible error (approximately 5\%) associated with this estimate (Martin and Thomas, 2011; Melson et al., 2011).

In order to test whether the square size correlates with number of trees and biomass, a linear regression using the statistical PAST package was applied (Hammer et al., 2001).

\section{RESULTS}

The size of the squares, the absolute number of individuals, tree density and average height of the trees varied among the squares as follows. TTN was the largest square $\left(24,817.1 \mathrm{~m}^{2}\right)$ while ACC was the smallest $\left(421.9 \mathrm{~m}^{2}\right)$. The largest number of individuals (203) was reported at PI, followed by TTN (128) and MD (61). SD presented the highest tree density (380.9 individuals $\mathrm{ha}^{-1}$ ), and JP the smallest (19.3 individuals $\mathrm{ha}^{-1}$ ). The average height of the trees ranged from 4.5 $\mathrm{m}$ to $11.9 \mathrm{~m}$, and the tallest individuals were found at MD. Considering the branched trees, TTN presented 42 individuals, a number that represents $33 \%$ of the total of its trees., Analogously: PLASC 9\%, JP 14\%, and VC $54 \%$ (Table I).

The structure of the communities varied among the squares. Figure 2 shows the tree distribution in different classes of DBH. Most of the VC and TTN individuals fall within the $5-10 \mathrm{~cm}$ DBH range $(64 \%$ and $38 \%$, respectively). ACC, JP, MD, PLASC, TTN and PI trees fall in all DBH classes. OB and JP have the largest trees, with about $63 \%$ and $41 \%$ of individuals with more than $30 \mathrm{~cm} \mathrm{DBH}$.

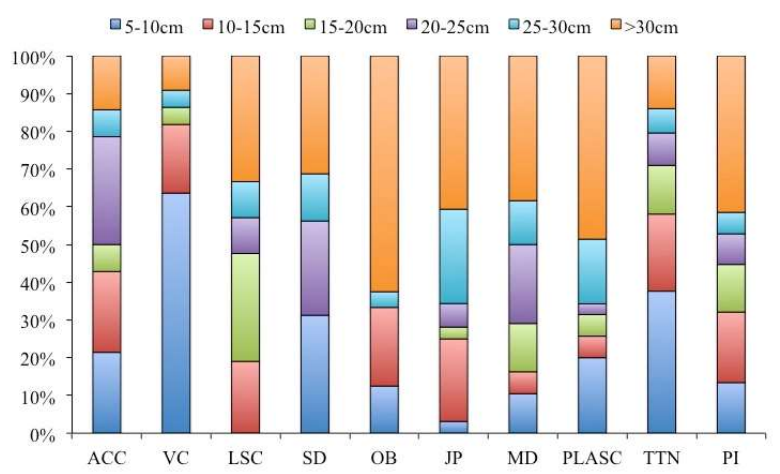

Figure 2 - Frequency distribution of branches in classes of DBH $\geq 5 \mathrm{~cm}$. Square names are as follows, and classes are represented in $\mathrm{cm}$. ACC-Antonio Cândido de Camargo, VC-Vicente Celestino, LSC-Largo Santa Cecilia, SD-Chão de Giz, OB-Olavo Bilac, JP-Júlio Prestes, MD-Marechal Deodoro, PLASC-Padre Luis Alves de Siqueira Castro, TTN-Torquato Tasso Neto, PI-Princesa Isabel.

Figura 2 -Distribuição de frequência de bifurcações em classes de diâmetro $\geq 5 \mathrm{~cm}$ em diferentes locais. As praças são indicadas como mostrado abaixo, e as classes são representadas em $\mathrm{cm}$. ACC-Antonio Cândido de Camargo, VC-Vicente Celestino, LSC-Largo Santa Cecilia, SD-Chão de Giz, OB-Olavo Bilac, JP-Júlio Prestes, MD-Marechal Deodoro, PLASC-Padre Luis Alves de Siqueira Castro, TTN-Torquato Tasso Neto, PIPrincesa Isabel.

\section{Revista Árvore 2020;44:e4417}


The use of a single allometric model may result in a skewed final value. Thus, we used five different models, which allowed to verify the range of the data by comparing the trend of each model.

Regarding the absolute contribution of biomass, PI showed the highest value of all squares, followed by MD and TTN. ACC, SD and LSC presented the lowest amount of total ABG biomass (Figure 3). In some cases, the variability of data provided by the different allometric models was quite high. As an example, Arevaldo's model yielded 74\% more biomass than Scatena's model for PI. This was also the trend for the squares with low biomass, such as ACC, which showed $76 \%$ more biomass, as calculated by Arevaldo's model, than that computed with Scatena's model.

Although TTN is larger in area than MD and its tree density is also higher, MD yielded the second greatest value of biomass, a result of the diametric structure of the squares since for $38 \%$ of the MD trees $\mathrm{DBH}$ is greater than $30 \mathrm{~cm}$, whereas for $38 \%$ of the TTN treesDBH ranges from 5 to $10 \mathrm{~cm}$.

Based on the different models, OB presented the greatest value of $\mathrm{ABG}$ biomass in relation to the total area of the square, even though this represents a comparatively small area. PI yielded the second highest biomass density. ACC, LSC and TTN yielded the lowest biomass densities (Figure 4). In general, Chave's and Tiepollo's models produced intermediate values of ABG in the different squares, while Scatena's and Arevaldo's models produced the lowest and the highest values, respectively.

Such differences in ABG biomass between squares with different structures may be attributed to a weak relationship between square area and the absolute number of trees. The increase in the number of trees was poorly explained by square area, as shown in Figure 4. Other attributes such as ABG biomass, tree density and ABG biomass density showed no significant relationships with square area.

\section{DISCUSSION}

Antônio Cândido de Camargo square showed the lowest number of trees, but its green area had a high tree density, indicating that it is a comparatively wellwooded square. The results do not show a clear trend correlating square size with the density of branches, as
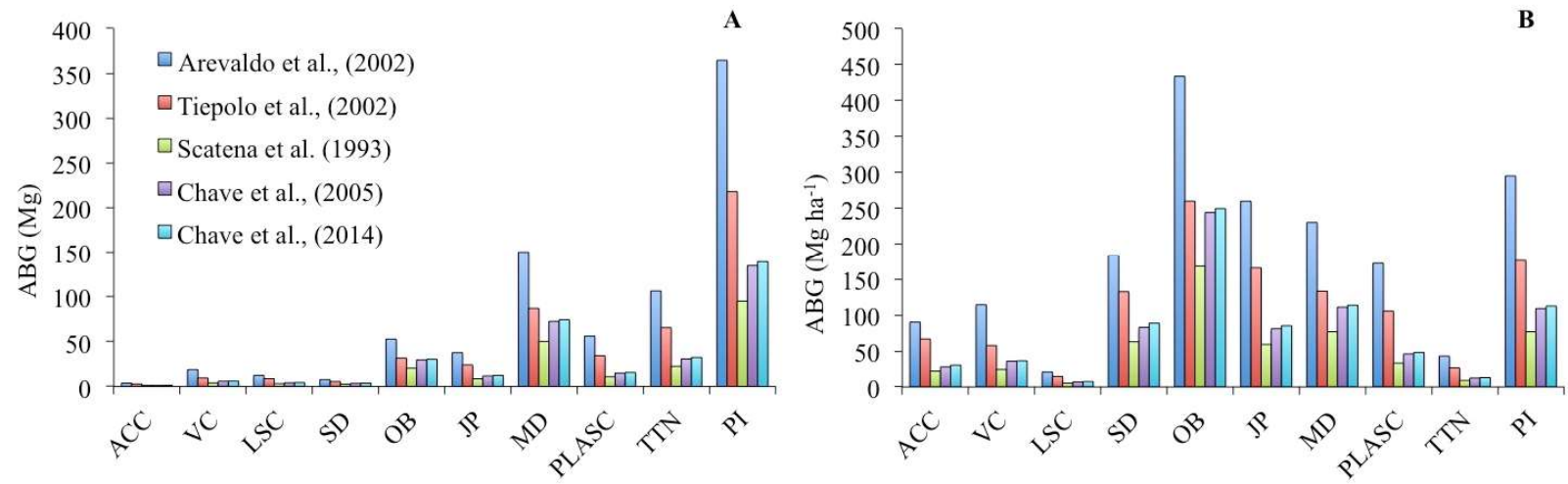

Figure 3 - Aerial biomass values along the studied squares. Arevalo et al. (2002) and Tiepolo et al. (2002) models consider only one variable (DBH in cm). Scatena et al. (1993) model considers two variables (DBH in $\mathrm{cm}$ and height in $\mathrm{m}$ ). Chave et al. (2005) and Chave et al. (2014) models consider three variables (DBH in $\mathrm{cm}$, height in $\mathrm{m}$ and wood density in $\mathrm{gcm}^{-3}$ ). The squares are indicated as follows: ACC-Antonio Cândido de Camargo, VC-Vicente Celestino, LSC-Largo Santa Cecilia, SD-Chão de Giz, OB-Olavo Bilac, JP-Julio Prestes, MD-Marechal Deodoro, PLASC-Padre Luis Alves de Siqueira Castro, TTN-Torquato Tasso Neto, PI-Princesa Isabel. In A) Total aerial biomass in different squares of the study according to the estimated models. In B) Aerial biomass per unit area in each studied square.

Figura 3 - Valores de biomassa aérea ao longo das praças estudadas. Os modelos de Arevalo et al. (2002) e Tiepolli et al. (2002) consideram apenas uma variável $(D B H \mathrm{em} \mathrm{cm})$. O modelo de Scatena et al. (1993) considera duas variáveis (DBH em $\mathrm{cm} e$ altura em m). Os modelos de Chave et al. (2005) e Chave et al. (2014) consideram três variáveis (DBH em cm, altura em $\mathrm{m}$ e densidade da madeira em $\mathrm{gcm}^{-3}$ ). As praças são indicadas da seguinte forma: ACC-Antonio Cândido de Camargo, VC-Vicente Celestino, LSC-Largo Santa Cecilia, SD-Chão de Giz, OB-Olavo Bilac, JP-Julio Prestes, MD-Marechal Deodoro, PLASC-Padre Luis Alves de Siqueira Castro, TTN-Torquato Tasso Neto, PI-Princesa Isabel. Em A) Biomassa aérea total em diferentes praças do estudo de acordo com os modelos estimados. Em B) Biomassa aérea por unidade de área em cada praça estudada.

Revista Árvore 2020;44:e4417 

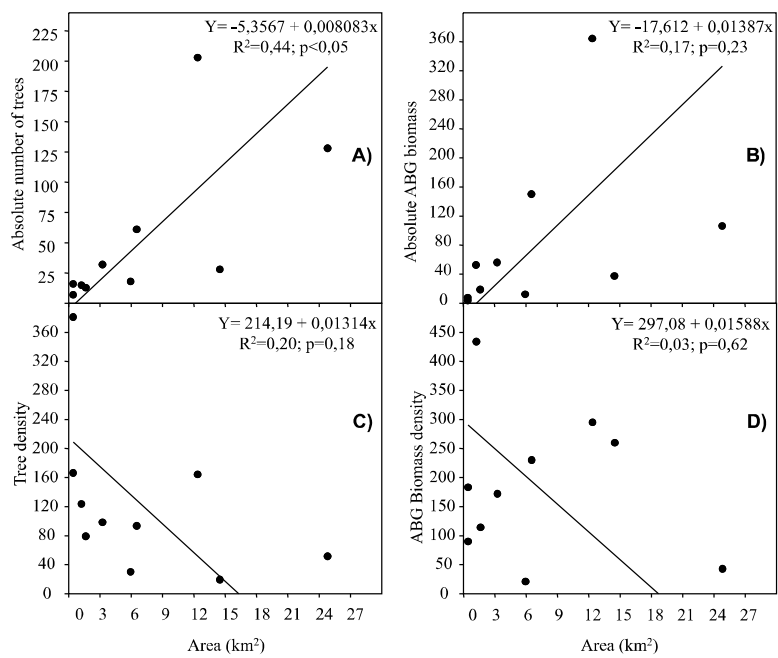

Figure 4 - Linear regression between area of the squares and number of trees (A), total ABG biomass (B), Tree density (C) and ABG biomass density (D).

Figura 4 - Regressão linear entre área das praças e número de árvores (A), biomassa $A B G$ total (B), Densidade da árvore $(C)$ e densidade de biomassa $A B G(D)$.

represented by PI, which is one of the largest squares in the study area with the greatest number of individuals. In terms of density, JP and LSC presented the lowest values, and both squares have a predominance of buildings and paved areas of historical and religious importance to local residents.

The tallest trees are on average found in MD and OB. Generally, compared to trees in dense forests, urban trees have variations in their architecture, which favor the formation of multiple branches and greater lateral development of the canopy. Proportionally, VC and TTN showed the greatest number of individuals with this morphology, which is aesthetically pleasing because of the shade, as well as important ecosystem services, such as thermal control (Lindberg and Grimmond, 2011; Nowak et al., 2013).

Regarding the proportion of branches in different DBH classes, the values found in this study point out that VC, SD and TTN present new or newly managed trees since they showed the highest percentage of trees in the smallest size class. Other authors who have studied the vegetation in urban areas have found similar results, such as Troian et al. (2011), who found a predominance of trees belonging to the smaller diameter classes in a fragment of urban green area in the metropolitan region of Porto Alegre in southern Brazil. Naturally, this type of trees in the green infrastructure are better for some ecosystem services, such as carbon sequestration, but are worse for others, such as thermal control.

This structural feature of public squares may highlight the need for proper management by public authorities, given the rapid city growth and the specific management of the green infrastructure in São Paulo, which occurs in a decentralized way (Benchimol et al., 2017). The expansion of present suburbs must be monitored and planned in relation to existing forest remnants so that construction activities respect the maintenance of biodiversity, the provision of ecosystem services, and the well-being of those who reside in such localities (Nowak et al., 2013).

Breuste (2012) reported the participation of local residents in the preservation of tree biodiversity in urban streets of Mendonza, Argentina, with special attention to residential areas. Similar public participation may alter the tree structure of town squares, reflecting the involvement of the local community in the conservation of green areas. This could ultimately result in varying the distribution of diameter size classes in urban areas, as well as control the amount of exotic species planted in such places (Zisenis, 2015; Lossová et al., 2016). It is important to highlight that although floristic composition is a key tool for treescape assessment, this paper focuses on the structure and biomass of the communities located in squares of the district of Santa Cecilia, in São Paulo city.

Hence, it is likely that the structure of the tree community in public green areas may differ from the center to suburbs.

Interestingly, we found a high percentage of large trees in almost all squares, accounting for total ABG biomass and contributing to carbon stocks. This can be explained by the historical age of the city center, although São Paulo has experienced an urban sprawl during the last century. The central part of the city is the oldest area, currently consisting of offices and a few houses. This fact makes these squares places frequented by transients.

Several authors have reported that total tree carbon is approximately $50 \%$ of the biomass (Chave et al., 2008; Lewis et al., 2009; Saatchi et al., 2011). Other researchers have shown a possible error (approximately $5 \%$ ) associated with this estimation (Martin and Thomas, 2011; Melson et al., 2011; Saner et al., 2012). 
In this sense, the carbon stock in urban trees is an extremely important ecosystem service once it works as a mechanism that compensates for local greenhouse gas emissions (Sharma et al., 2010).

Corroborating this statement, Zhao et al. (2010) showed a significant absorption of $\mathrm{CO}_{2}$ emitted by industrial sources in Hangzhou, China, by urban trees. The authors explained that approximately $18 \%$ of total $\mathrm{CO}_{2}$ emitted annually was uptaken by urban vegetation alone.

In the same way, Russo et al. (2015) pointed out that public squares in Bolzano, Italy, stocked approximately $0.61 \mathrm{~kg} \mathrm{CO}_{2} \mathrm{ha}^{-1}$ year $^{-1}$, playing an important role as a carbon sink. The authors noted the important role of treescapes in the $\mathrm{C}$ sink.

Timilsina et al. (2014) also showed that urban trees were responsible for about $5 \%$ uptake of anthropogenic emissions in the US State of Florida. The effectiveness of urban green areas in the USA prevented 850 casualties and 670,000 cases of acute respiratory symptoms in 2010 (Nowak et al., 2014).

Based on United Nations recommendations, Martins and Araujo (2014) mentioned that each city must have $12 \mathrm{~m}^{2}$ of green area per inhabitant. By 2030, some estimates predict that more than five million people will inhabit urban centers (UNFPA, 2015). Thus, it very important to quantify the biomass stocked in urban trees and their potential for sequestering carbon from the atmosphere.

Such information may be used to develop specific public policies for the protection and maintenance of urban green areas, such as the PLANPAVEL program for São Paulo City, which integrates the Municipal System of Protected Areas, the Green Areas and Free Spaces program (SAPAVEL) and the Municipal Plan of Urban Afforestation. Some public squares in this study showed high values of biomass per hectare compared to some areas of native Atlantic Forest, the biome of the local study. Rolim et al. (2005) found above-ground biomass of $334.5 \mathrm{Mg} \mathrm{ha}^{-1}$ in Linhares, southeastern Brazil, and Alves et al. (2010) found a total above-ground biomass of $239.3 \mathrm{Mg} \mathrm{ha}^{-1}$ in the same phytophysiognomy (submontane) in Ubatuba.

Proportionally, OB had the largest above-ground biomass per hectare, followed by PI. This demonstrates that despite the importance of tree density in a green area for carbon stock, other attributes are equally important, for example, the vertical and horizontal structure of the community. This is reinforced by MD, which has the third highest density of trees, and, on average, the tallest trees. Brown and Iverson (1992) showed that a DBH of $100 \mathrm{~cm}$ represents a biomass equivalent to 610 trees with $10 \mathrm{~cm}$ of $\mathrm{DBH}$. Although this result was obtained for an area of Ombrophilus Dense Forest in the Amazon region, it can be inferred that diameter and biomass have no direct and proportional relationship and an individual's biometric values can be a decisive factor in higher or lower carbon stocks.

Special attention has been given to the best allometric models that fit these tree communities. The results also showed that PI and ACC presented completely different biomass profiles, highlighting the heterogeneity of treescape ABG biomass in Santa Cecília District in the central region of São Paulo City. A large range of ABG values yielded by the different allometric models was also found, mainly in PLASC, with approximately $81 \%$ of variation in ABG biomass, when Arevaldo's and Scatena's models were used. McHale et al. (2009) tested different allometric equations in an urban green area in the U.S. State of Colorado and found more than $300 \%$ difference among the equations, reinforcing the need for allometric models specific to urban green areas.

Interestingly, it was observed that the TTN total area is almost four times that of MD and that it presents more than twice the absolute number of trees. Yet it still yields a lower amount of ABG biomass. It should be noted that the average TTN tree heights is almost three times shorter than those of MD, resulting in the smallest amount of stored biomass, which emphasizes the importance of the community vertical structure to the stock of ABG biomass.

Another important issue related to the use of public green areas is the maintenance of biodiversity. Several squares play an important role in leisure, while others are important for their carbon uptake (Mazzei et al., 2007). An important consideration for public policy makers in São Paulo is to determine if trees can be planted in any empty space in urban green areas, since they promote shade and thermal comfort, as well as shelter for the biodiversity of urban arthropods and birds. Our results show that the increase in green area responds for only $42 \%$ of total number of individuals, which demonstrates the potential of these squares for planting more trees.

Revista Árvore 2020;44:e4417 


\section{CONCLUSION}

The present work allowed to verify that the biometric characteristics, related to the DBH classes and the height of the trees, varied throughout the squares of the study area. The frequency distribution of branch diameters in the squares varied according to regions. Other structural features also varied among the areas, such as average height of trees.

The study draws attention to the antagonistic results observed when analyzing the total biomass per square and the density of biomass per square, which shows that larger areas are responsible for the greater amount of absolute biomass stored in trees; however, when analyzing in terms of biomass density, it is observed that smaller squares are more vegetated or have trees with larger diameters, promoting an important ecosystem service (carbon stock).

This information may assist the Secretariat for Green and Environment in the planning of future green corridor, as well as improving existing programs that require ecological information on public green spaces, such as PLANPAVEL and the Municipal Urban Afforestation Plan. So, as a positive point of the present study, it is possible to highlight that it is a contribution to public policies aimed at the management of the green infrastructure of São Paulo City. This is because the results showed that the higher biomass densities, verified in the smaller squares, indicate that the larger squares have potential for the planting of more trees, promoting thus more ecosystem services to the city.

In addition, it is possible to highlight the pioneerism of the present study in the effort to estimate biomass values in the present green infrastructure of São Paulo city. Lastly, we highlight the importance of the expansion of studies that seek the development of allometric models specific to the vegetation of the green areas of São Paulo City. This is especially important because the results indicate a high variability of data among biomass values calculated by different allometric models, for example, the one obtained using the Arevalo's and Scatena's models.

\section{REFERENCES}

Alves LF, Vieira SA, Scaranello MA, Camargo PB, Santos FAM, Joly CA, et al. Forest structure and live aboveground biomass variation along an elevational gradient of tropical Atlantic moist forest (Brazil). Forest Ecology and Management. 2010;260(5):67969. doi: 10.1016/j.foreco.2010.05.023

Arevalo LA, Alegre JC, Vilcahuaman LJM. Metodologia para estimar o estoque de carbono em diferentes sistemas de uso da terra. Colombo, PR: Embrapa Florestas; 2002.

Benchimol JF, Lamano-Ferreira APN, Ferreira ML, Cortese TTP, Ramos HR. Decentralized management of public squares in the city of São Paulo, Brazil: implications for urban green spaces. Land Use Policy. 2017;63:418-27. doi: 10.1016/j. landusepol.2017.02.004

Breuste JH. Investigations of the urban street tree forest of Mendonza, Argentina. Urban Ecosystems. 2012;16:801-18. doi: 10.1007/s11252-012-0255-2

Brown S, Iverson LR. Biomass estimates for tropical forest. World Resources Review. 1992;4:366-84.

Burger DM, Delitti WBC. Allometric models for estimating the phytomass of a secondary Atlantic Forest area of southeastern Brazil. Biota Neotropica. 2008;8(4):131-36. doi: 10.1590/S167606032008000400012

Chave J, Andalo C, Brown S, Cairns MA, Chambers JQ, Eamus D, et al. Tree allometry and improved estimation of carbon stocks and balance in tropical forests. Oecologia. 2005;145:87-99. doi: 10.1007/ s00442-005-0100-x

Chave J, Condit R, Muller-Landau HC, Thomas SC, Ashton PS, Bunyavejchewin S, et al . Assessing Evidence for a Pervasive Alteration in Tropical Tree Communities. PLoS Biolology. 2008;6(3):-e45. doi: 10.1371/journal.pbio.0060045

Chave J, Rejou-Mechain M, Búrquez A, Chidumayo E, Colgan MS, Delitti WBC, et al. Improved allometric models to estimate the aboveground biomass of tropical trees. Global Change Biology. 2014;20(10):3177-90. doi: 10.1111/gcb.12629

Clark JS, Carpenter SR, Barber M, Collins S, Dobson A, Foley JA, et al. Ecological Forecasts: an emerging imperative. Science. 2001;293(5530):65760. doi: $10.1126 /$ science.293.5530.657

Díaz-Porras DF, Gaston KJ, Evans KL. 110 Years of 
change in urban tree stocks and associated carbon storage. Ecology and Evolution. 2014;4(8):1413-22. doi: $10.1002 /$ ece 3.1017

Eisenlohr PV, Alves LF, Bernacci LC, Padgurschi MCG, Torres RB, Prata EMB, et al. Disturbances, elevation, topography and spatial proximity drive vegetation patterns along an altitudinal gradient of a top biodiversity hotspot. Biodiversity and Conservation. 2013;22:2767-83. doi: 10.1007/s10531-013-0553-x

European Commission - EC. Green infrastructure (GI) - enhancing Europe's Natural Capital. COM(2013)249. Brussels; 2012.

European Environment Agency - EEA. Green infrastructure and territorial cohesion. Technical Report 2011/18. Copenhagen; 2011.

Ferreira AB, Ribeiro AP, Ferreira ML, Kniess CT, Quaresma CC, Lafortezza R, et al. A Streamlined Approach by a Combination of Bioindication and Geostatistical Methods for Assessing Air Contaminants and Their Effects on Human Health in Industrialized Areas: a case study in southern Brazil. Frontiers in plant science. 2017a;8:1575. doi:10.3389/fpls.2017.01575. a

Ferreira ML, Ribeiro AP, Albuquerque CR, Ferreira APNL, Figueira RCL, Lafortezza R. Air contaminants and litter fall decomposition in urban forest areas: The case of São Paulo-SP, Brazil. Environmental research. 2017b;155:314-20. doi:10.1016/j.envres.2017.02.023

Ferreira ML, Uchiyama EA. Litterfall assessement in a fragment of secondary tropical forest, Ibiúna, SP, Southeastern Brazil. Revista Árvore. 2015;39(5):79199. doi: 10.1590/0100-67622015000500002

Fundação Sistema Estadual de Análise de dados - SEAD. 2014. Governo do Estado de São Paulo. Resenha de Estatística Vitais do Estado de São Paulo. Disponível em em $<$ https://www.seade.gov. br/produtos/midia/spdemografico/spdemog_jan2014. pdf $>$. Acesso em 30 maio 2017.

Hammer O, Harper DAT, Ryan PD. PAST: paleontological statistics software package for education and data analysis. Palaeontologia Electronica. 2001;4(1):1-9.

Higuchi N, Santos J, Lima AJN. Biometria Florestal.
Apostila. Manaus: Instituto Nacional de Pesquisas da Amazônia; 2008.

Instituto de Astronomia, Geofísica e Ciências Atmosféricas da Universidade de São Paulo - . Boletim Climatológico Anual da Estação Meteorológica do IAG/USP, 2014. Disponível em: $<$ http://www.estacao.iag.usp.br/Boletins/2014.pdf.>. Acesso em 24 april 2015.

Prefeitura da Cidade de São Paulo - São Paulo. Dados demográficos dos distritos pertencentes às Subprefeituras. Disponível em < https:// www.prefeitura.sp.gov.br/cidade/secretarias/ subprefeituras/subprefeituras/dados_demograficos/ index.php? $\mathrm{p}=12758>$. Acesso em 09 de junho de 2020.

Kabisch N, van den Bosch M, Lafortezza R. The health benefits of nature-based solutions to urbanization challenges for children and the elderly-A systematic review. Environmental Research. 2017;159:362-73. doi: 10.1016/j. envres.2017.08.004

Keesstra S, Nunes J, Novara A, Finger D, Avelar D, Kalantari Z, et al. The superior effect of nature based solutions in land management for enhancing ecosystem services. Science of the Total Environment. 2018;610-611:997-1009. doi: 10.1016/j.scitotenv.2017.08.077

Lafortezza R, Davies C, Sanesi G, Konijnendijk CC. Green Infrastructure as a tool to support spatial planning in European urban regions. iForestBiogeosciences and Forestry. 2013;6:102-108. doi: 10.3832/ifor0723-006

Lapola DM, Martinelli LA, Peres CA, Ometto JPHB, Ferreira ME, Nobre CA, et al . Pervasive transition of the Brazilian land-use system. Nature Climate Change. 2014;4:27-35. doi: 10.1038/nclimate2056

Lewis SL, Lopez-Gonzalez G, Sonké B, AffumBaffoe K, Baker TR, Ojo LO, et al. Increasing carbon storage in intact African tropical forests. Nature. 2009;457:1003-06. doi: 10.1038/ nature 07771

Malhi Y, Grace J. Tropical forests and atmospheric carbon dioxide. Trends in Ecology and Evolution. 2000;15(8):332-37. doi: 10.1016/S01695347(00)01906-6

Revista Árvore 2020;44:e4417 
Lindberg F, Grimmond CSB. Nature of vegetation and building morphology characteristics across a city: Influence on shadow patterns and mean radiant temperatures in London. Urban Ecosystems. 2011;14:617-34. doi: 10.1007/s11252-011-0184-5

Lossová Z, Chytrý M, Danihelka J, Tichý L, Ricotta C. Biotic homogenization of urban floras by alien species: the role of species turnover and richness diferences. Journal of Vegetation Science. 2016;27(3):452-59. doi: 10.1111/jvs. 12381

Martin AR, Thomas SC. A reassessment of carbon content in tropical trees. PLoS One. 2011;6(8):e23533. doi: 10.1371/journal. pone. 0023533

Martins RTP, Araújo RS. Benefícios dos Parques Urbanos. Perspectivas Online: ciências humanas e sociais aplicadas. 2014;10(4):38-44.

Mazzei K, Colesanti MTM, Santos DG. Áreas verdes urbanas, espaços livres para o lazer. Revista Sociedade \& Natureza. 2007;19(1):33-43.

McDonald RI, Marcotullio PJ, Güneralp B. Urbanization and global trends in biodiversity and ecosystems services. In: Elmqvist T, Fragkias M, Goodness J, Güneralp B, Marcotullio PJ, McDonald RI, et al. (eds). Urbanization, biodiversity and ecosystems services: challenges and opportunities. A global assessment. Springer Dordrecht; 2013.

McHale MR, Burke IC, Lefsky MA, Peper PJ, McPherson EG. Urban forest biomass estimates: is it important to use allometric relationships developed specifically for urban trees?. Urban Ecosystems. 2009;12:95-113. doi: 10.1007/s 11252-009-0081-3

Melson SL, Harmon ME, Fried JS, Domingo JB. Estimates of live-tree carbon stores in the Pacific Northwest are sensitive to model selection. Carbon Balance Management. 2011;6(2): 1-16. doi: 10.1186/1750-0680-6-2

Moro MF, Westerkamp C, Araújo FS. How much importance is given to native plants in cities treescape? A case study in Fortaleza, Brazil. Urban Forestry \& Urban Greening. 2014;13(2):365-74. doi: $10.1016 /$ j.ufug. 2014.01.005

Nowak DJ, Hirabayashi S, Bodine A, Greenfield E. Tree and forest effects on air quality and human health in the United States. Environmental Pollution. 2014;193:119-29. doi:10.1016/j.envpol.2014.05.028

Nowak DJ, Hoehn RE, Bodine AR, Greenfield EJ, O'neil-Dunne J. Urban forest structure, ecosystem services and change in Syracuse, NY. Urban Ecosystems. 2013;19:1455-77. doi 10.1007/s11252-013-0326-z

Oertli B, Joye DA, Castella E, Juge R, Cambin D, Lachavanne JB. Does size matter? The relationship between pond area and biodiversity. Biological Conservation. 2002;104(1):59-70. doi:10.1016/ S0006-3207(01)00154-9

Rolim SG, Jesus RM, Nascimento HEM, Couto HTZ, Chambers JQ. Biomass change in an Atlantic tropical moist forest: the ENSO effect in permanent sample plots over a 22-year period. Oecologia. 2005;142:238-46. doi: 10.1007/s00442-004-1717-x

Russo A, Escobedo FJ, Timilsina N, Zerbe S. Transportation carbon dioxide emission offsets by public urban trees: a case study in Bolzano, Italy. Urban Forestry and Urban Greening. 2015;14(2):398-03. doi:10.1016/j.ufug.2015.04.002

Saatchi SS, Harris NL, Brown S, Lefsky M, Mitchard ETA, et al. Benchmark map of forest carbon stocks in tropical regions across three continents. Proceedings of the National Academy of Sciences. 2011;108(24):9899-04. doi: 10.1073/ pnas. 1019576108

Saleska SR, Miller SD, Matross DM, Goulden ML, Wofsy SC, Rocha HR, et al. Carbon in Amazon Forest: unexpected seasonal fluxes and disturbanceinduced losses. Science. 2003;302(5650):1554-57. doi: $10.1126 /$ science. 1091165

Saner P, Loh YY, Ong RC, Hector A. Carbon Stocks and M, Fluxes in Tropical Lowland Dipterocarp Rainforests in Sabah, Malaysian Borneo. PLoS One. 2012;7(1):e29642. doi:10.1371/journal. pone. 0029642

Sanesi G, Colangelo G, Lafortezza R, Calvo E, Davies C. Urban green infrastructure and urban forests: a case study of the Metropolitan Area of Milan. Landscape Research. 2017; 42(2):164-75. doi: 10.1080/01426397.2016.1173658

Scatena FN, Silver W, Siccama T, Johnson A, Sánchez MJ. Biomass and nutrient content of

Revista Árvore 2020;44:e4417 
the Bisley Experimental Watersheds, Luquillo Experimental Forest, Puerto Rico, before and after Hurricane Hugo, 1989. Biotropica. 1993;25(1):1527. doi: $10.2307 / 2388975$

Scolforo HF, Scolforo JRS, Mello CR, Mello JM, Ferraz Filho AC. Spatial Distribution of Aboveground Carbon Stock of the Arboreal Vegetation in Brazilian Biomes of Savanna, Atlantic Forest and Semi-Arid Woodland. PLoS One. 2015;10(6):e0128781. doi: 10.1371/journal. pone. 0128781

Sharma AR, Kharol SK, Badarinath KVS. Influence of vehicular traffic on urban air quality - A case study of Hyderabad, India. Transp. Res. Part D: Transp. Environmental. 2010;15(3):154-59. doi: 10.1016/j.trd.2009.11.001

Tabarelli M, Montovani W. Clareiras naturais e a riqueza de espécies pioneiras em uma Floresta Atlântica Montana. Revista Brasileira de Biologia. 1990;59(2):251-61.

Tanus MR, Pastore M, Bianchini RS, Gomes EPC. Estrutura e composição de um trecho de Mata Atlântica no Parque Estadual das Fontes do Ipiranga, São Paulo, SP, Brasil. Hoehnea. 2012;39(1):157-68. doi:10.1590/S2236-89062012000100010

Tiepolo G, Calmon M, Feretti AR. Measuring and monitoring carbon stocks at the Guaraqueçaba climate action project, Paraná, Brazil. In: Proceedings of the International Symposium on Forest Carbon Sequestration and Monitoring; 2002. p. 11-15.

Timilsina N, Staudhammerc CL, Escobedo FJ, Lawrence A. Tree biomass, wood waste yield, and carbon storage changes in an urban forest. Landscape and Urban Planning. 2014;127:18-27. doi: 10.1016/j. landurbplan.2014.04.003

Troian LC, Käffer MI, Müller SC, Troian VR, Guerra J, Borges MG, et al . Florística e padrões estruturais de um fragmento florestal urbano, região metropolitana de Porto Alegre, RS, Brasil. Iheringia Série Botânica. 2011;66(1):5-16.
United Nation Population Fund. Urbanization UNFPA. Urbanization, overview. Relatório das Nações Unidas. Divulgado em 24 de abril de 2015. Site das Nações Unidas. Disponível em: $<$ http:// www.unfpa.org/urbanization>. Acesso em 8 de junho de 2020.

Vieira S, Camargo PB, Selhorst D, Silva R, Hutyra L, Chambers JQ, et al. Forest structure and carbon dynamics in Amazonian tropical rain forest. Oecologia. 2004;140:468-79. doi: 10.1007/s00442004-1598-z

Vieira SA, Alves LF, Aidar M, Araújo LS, Baker $\mathrm{T}$, Batista JLF, et al. Estimation of biomass and carbon stocks: the case of the Atlantic Forest. Biota Neotropica. 2008;8(2):21-29. doi:10.1590/S167606032008000200001

Villard MA, Metzger JP. Beyond the fragmentation debate: a conceptual model to predict when habitat configuration really matters. Journal of Applied Ecology. 2014;51(2):309-18. doi: 10.1111/13652664.12190

Weissert LF, Salmond JA, Schwedenmann L. A review of the current progress in quantifying the potential of urban forests to mitigate urban $\mathrm{CO} 2$ emissions. Urban Climate. 2014;8:100-25. doi: 10.1016/j.uclim.2014.01.002

Zhang K, Castanho ADA, Galbraith DR, Moghim S, Levine NM, Bras RL, et al . The Fate of Amazonian Ecosystems over the Coming Century Arising from Changes in Climate, Atmospheric CO2 and Landuse. Global Change Biology. 2015;21(7):2569-87. doi: $10.1111 / \mathrm{gcb} .12903$

Zisenis M. Alien plant species: a real fear for urban ecosystems in Europe?. Urban Ecosystems. 2015;18:355-70. doi:10.1007/s11252-014-0400-1

Zhao M, Kong ZH, Escobedo FJ, Gao J. Impacts of urban forests on offsetting carbon emissions from industrial energy use in Hangzhou, China. Journal of Environmental Management. 2010;91(4):807-13. doi: 10.1016/j.jenvman.2009.10.010 